\title{
THE COMPARISON OF JOHN CALVIN AND KARL BARTH ON THE DOCTRINE OF UNION WITH CHRIST
}

\author{
Jason Zhao \\ Puritan Reformed Theological Seminary, USA \\ Korespondensi: jason.ires@gmail.com
}

\begin{abstract}
This article will continue to explore the influences of Calvin and Barth's different ontology on their distinct doctrine of union with Christ. After presenting Calvin's doctrine of union with Christ and Barth's teaching of participation in Christ, I will bring together the work of the previous study through comparison and evaluation. Although both Calvin and Barth adopt a Christocentric approach and similarly have a distinction between believers' objective and subjective union with Christ, their distinct ontological presuppositions, within their own philosophical and cultural contexts, drive Calvin to a theology of union with "being" and Barth to that of union with "doing". In that sense, Barth, in line with his actualistic ontology, does not only depart from Calvin in his doctrine of election as he claims, but also in his doctrine of participation in Christ or union with Christ, although he retains the Calvinist terminology.
\end{abstract}

KEYWORDS: John Calvin; Karl Barth; Union with Christ; de jure participation in Christ.

ABSTRAK: Artikel ini akan melanjutkan mendalami pengaruh perbedaan ontologi pemikiran Calvin dan Barth terhadap doktrin mereka mengenai kesatuan dengan Kristus. Setelah memaparkan doktrin Calvin akan kesatuan dengan Kristus dan ajaran Barth mengenai partisipasi di dalam Kristus, penulis akan memakai studi sebelumnya untuk perbandingan dan evaluasi. Meskipun baik Calvin dan Barth menggunakan pendekatan Kristosentris dan sama-sama memiliki 
keunikan antara kesatuan orang percaya dengan Kristus secara obyektif dan subyektif, keunikan presuposisi ontologis mereka, di dalam konteks filsafat dan kultur mereka masing-masing, telah mendorong Calvin kepada teologi kesatuan dengan 'keberadaan' dan dalam kasus Barth kepada kesatuan dengan 'perbuatan'. Dalam pengertian ini, Barth, sejalan dengan ontologi aktualistiknya, bukan hanya meninggalkan Calvin dalam doktrin pemilihan saja, tapi juga dalam doktrin partisipasi di dalam Kristus, sekalipun dia menggunakan kosakata Calvinist.

KATA KUNCl: Yohanes Calvin; Karl Barth; Kesatuan dengan Kristus; Partisipasi di dalam Kristus secara de jure.

\section{Introduction}

The divergence between Calvin and Barth becomes greater when it comes to the doctrine of union with Christ per se.

\section{Union with Christ in Calvin}

When God the Father wills a people and hands over them to Christ by His decree of engrafting them into the body of Christ, an objective eternal union between the elect and Christ, for Calvin, is somehow established. But does Calvin further develop this objective union in the incarnate life history of Christ? Some studies in recent years prove that Calvin does have an objective incarnational union with Christ in mind, which is chiefly revealed in his correspondence with the Italian Reformer Peter Martyr Vermigli (1499-1562). ${ }^{1}$ But is that incarnational union really the continuity of Calvin's eternal objective union between the elect and Christ? This section will carry on the previous study and try to answer

\footnotetext{
1 It is T. F. Torrance who suggests the possibility of a redemptive, incarnational union in Calvin. See Torrance, The School of Faith: Catechisms of the Reformed Church (London: James Clarke, 1959). W. Duncan Rankin has a detailed study of Calvin's incarnational union in his W. Duncan Rankin, "Carnal Union with Christ in the Theology of T. F. Torrance," Ph.D. thesis (University of Edinburgh, 1994). See also A.N.S. Lane, "The Quest for the Historical Calvin", Evangelical Quarterly (1983): 113. I would like to express my appreciation to Dr. Rankin for his generous sharing of his articles and dissertation, which are of great help for me in this study.
} 
the question by examining both the objective and subjective aspects of believers' union with Christ in Calvin.

\section{Incarnational Union with Christ in Calvin}

In March 1555, Vermigli sent a letter to Calvin to discuss his understanding of a threefold communion with Christ, after the sequence of incarnational, then the intermediate mystical, and lastly spiritual. ${ }^{2}$ According to Vermigli, Jesus Christ in His incarnation brings the first level of communion with Christ. In the incarnation of Jesus Christ, "the whole human race already hold in this wise communion with Christ." 3 How does that happen? In assuming human nature, Jesus Christ assumes the same "corporal flesh and blood" with all humanity, and thus, all believers and unbelievers are "in fact men, as He was man." 4 For Vermigli, this incarnational communion is realized biologically or genetically "through our origin from our parents", 5 and thus universal in scope but "very general and feeble", which has no saving work. ${ }^{6}$ Only when the Holy Spirit intervenes, by generating saving faith in the elect, can they be engrafted into Christ's body and enlivened, entering into the mystical communion with Christ. ${ }^{7}$ The renovating power of Spirit continually works day by day to shape the believers more and more conformable to Christ until the glorious eschaton, which is the spiritual communion with Christ. ${ }^{8}$

In his response to Vermigli on 8 August 1555, Calvin firstly affirms that the matter of union with Christ "is one of vast importance." ${ }^{9}$ At the end, he concludes:

\footnotetext{
2 Peter Martyr Vermigli, "Martyr to Calvin, Strasburgh, March 8, 1555," in Cleanings of a Few Scattered Ears, ed. Gorham, G. C. (London: Bell and Daldy, 1857), 343. Emphasis added.

3 Ibid., 342.

4 Ibid.

5 Ibid., 343 .

6 Ibid, 342.

7 Ibid, 343.

8 Ibid, 342-343.

9 John Calvin, "Calvin to Martyr, Geneva, August 8, 1555," in Cleanings of a Few Scattered Ears, 349.
} 
Were I teaching any other person, I should follow up this subject more diffusely; in addressing you, I have glanced at it briefly, with the simple view of showing you that we entirely agree in sentiment. ${ }^{10}$

So, Calvin entirely approves Vermigli's understanding of the threefold communion with Christ.

Concerning the incarnational communion between Christ and all humanity, Calvin replies:

That the Son of God put on our flesh, in order that He might become our Brother, partaker of the same nature, - is a Communion on which I do not mean to speak here: for I propose to treat only [mystic and spiritual communion].11

As it shows, while affirming the existence of this incarnational communion, Calvin does not feel necessary to further expand this universal "general and feeble" communion; rather, he prefers to focus on the other more important existential twofold union, the believers' engrafting into Christ.

Calvin maintains this attitude in his later Institutes and biblical commentaries. He admits that there is a "fellowship of nature" between Christ and human being, because "Christ is clearly declared to be comrade and partner in the same nature with us." 12 In his commentaries on 1 Timothy 2:5, Calvin also argues that "by sharing our nature", Christ "is joined to us" and stretches out a brotherly hand to all men. ${ }^{13}$ However, that does not mean even the unbelievers are sharing Christ's brotherhood. Only those with faith can be engrafted spiritually into the body of Christ and really enjoy the brotherhood fellowship. ${ }^{14}$

Therefore, we could conclude that Calvin's incarnational union is not the continuity of his implicit objective union with Christ in election.

\footnotetext{
$10 \quad$ Ibid., 352.

11 Ibid., 349.

12 John Calvin, Institutes of the Christian Religion, ed. John T. McNeill, trans. Ford Lewis Battles (Philadelphia: Westminster Press, 1960), II.13.2.

13 Quoted from Rankin, "Carnal Union with Christ in the Theology of T. F. Torrance”, 196.

14 Calvin, Institutes, II.13.2.
} 
Because the latter is only for the elects who are predestined to be engrafted into the body of Christ, while the incarnational union is universal in scope, which is a "very general and feeble" communion merely on the basis of shared human nature with Christ. Moreover, the elect's objective union with Christ in eternal election has Christ as the mediator and executor, which means the elects already have the pledge or guarantee for their saving union with Christ in time. But the feeble incarnational union is not sufficient to guarantee us to dwell in Christ. For Calvin, neither the elect's eternal objective union with Christ nor the universal incarnational union has saving work by itself. Without the existential union with Christ, we still cannot share the rich blessing in Christ.

\section{Existential Union with Christ in Calvin}

In his 1555 Correspondence with Vermigli, Calvin also presents his view on this existential saving union with Christ. Following Vermigli's order, Calvin opens his letter with the discussion of the mystical union, "which flows from His heavenly influence, and breathes life into us, and makes us to coalesce into one body with Himself." 15 He agrees with Vermigli that the faithful can enjoy a "sacred unity" with Christ "our head," by which "the Son of God engrafts us into His body." 16 This communion is so intense and mystical that Christ's flesh and blood could even be "called our food."17 How does that happen? Calvin frankly confesses that is "far deeper than the measure of my understanding"; therefore, "I rather receive this mystery, than labour to comprehend it." 18 Like Vermigli, Calvin attributes this mystical union solely to the work of Holy Spirit. "[N]either could the flesh of Christ be life-giving by itself, nor could its efficacy reach as far as us," Calvin stresses, "except through the

\footnotetext{
15 John Calvin, “Calvin to Martyr, Geneva, August 8, 1555”, 349.

16 Ibid., 349. Notice here, Calvin employs the same imagery of "engrafted into" and "head and body" as Vermigli when addressing the mystical communion.

17 Ibid.

18 Ibid.
} 
immense operation of the Spirit."19 Only the Holy Spirit can overcome the physical distance between the heavenly savior and his people.

Then, Calvin goes on to discuss "a second communion", which "is the fruit and effect of the former." 20 Building on the former mystical union, Calvin says, Christ "exerts a second influence of His Spirit, enriching us by His gifts" as following:

Hence, - that we are strong in hope and patience, - that we soberly and temperately keep ourselves from worldly snares, - that we strenuously bestir ourselves to the subjugation of carnal affections, - that the love of righteousness and piety flourishes in us, - that we are earnest in prayer, - that meditation on the life to come draws us upwards, -this, I maintain, flows from that second Communion, by which Christ, dwelling in us not ineffectually, brings forth the influence of His Spirit in His manifest gifts. ${ }^{21}$

All of these abundant spiritual gifts, according to Calvin, are the subsequent effects of Christ's dwelling in us, and thus, only for the true converts as well. Undoubtedly, Calvin is echoing Vermigli's spiritual communion with Christ, the mark of which is the strong dynamic progress of believers' spiritual life. In this spiritual union, Calvin continually argues, believers experience that "the life of Christ increases in them" and "He daily offers Himself to be enjoyed by them." ${ }^{22}$

So, in line with Vermigli, Calvin had a twofold existential union in mind. However, this distinction between mystical and spiritual union with Christ was not further explored in Calvin's 1559 Institutes. According to Tamburello's statistics, the terms of "mystical union" and "spiritual union" appears only twice in Calvin's Institutes..$^{23}$ Instead of using abstract language, Calvin prefers to adopt biblical illustrations, the most frequent "engrafting," the "joining together of Head and members," the "husband and wife marriage," "put on Christ," and so on, to explain

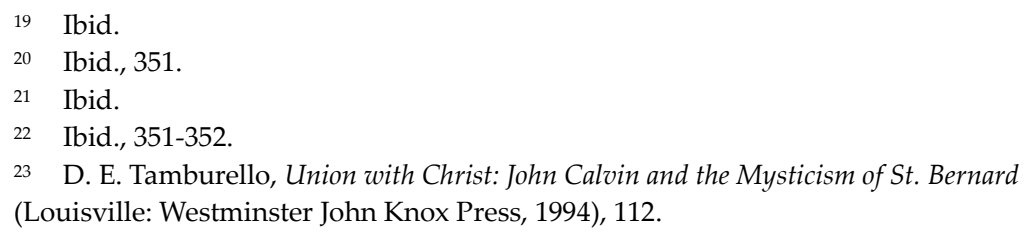


our union with Christ. The underlying reason is very likely the incomprehensibility of this unio mystica. It is very hard to find the appropriate terminology to denominate this twofold existential union. Rankin rightly points out that "the terminology involved can be rather cumbersome," due to the fact that the mystical union is no less "of the spirit" than the latter, while the spiritual union is no less "mysterious" than the former. ${ }^{24}$ Apparently, for Calvin, the distinction between mystical and spiritual union cannot fully convey the nuances of believers' existential union with Christ. To better grasp Calvin's thoughts on this, now let us turn to Calvin's 1559 Institutes to study the nature of this saving union.

\section{The Nature of Calvin's Existential Union with Christ}

\section{A Mystical Union}

As mentioned above, Calvin, rather than defining with abstract languages, prefers to use biblical illustrations to picture this existential union with Christ. The chief reason is that our union with Christ, for Calvin, is essentially mysterious in nature.

For example, Calvin often employs the illustration of a husband and wife in marriage to explain this unio mystica. In his commentary on Ephesians 5:32, where Paul refers to marriage as the symbol of the mystical union between Christ and the church, Calvin writes explicitly:

This is a great mystery; by which he means, that no language can explain fully what it implies. It is to no purpose that men fret themselves to comprehend, by the judgment of the flesh, the manner and character of this union...For my own part, I am overwhelmed by the depth of this mystery, and am not ashamed to join Paul in acknowledging at once my ignorance and my admiration. ${ }^{25}$

\footnotetext{
24 Rankin, "Carnal Union with Christ", 185.

25 John Calvin, Commentary, Ephesians 5:32. Accessed December 6, 2016.

http://www.ccel.org/ccel/calvin/calcom41.iv.vi.vi.html.
} 
Following Paul, Calvin feels "overwhelmed by the depth of this mystery." So instead of being speculative, Calvin encourages each of us to join him and Paul to acknowledge our ignorance and admiration, to "labor more to feel" or to experience this union, rather than to investigate this mystery. ${ }^{26}$ In fact, Calvin, for at least seven times in his Institutes, "uses the word arcanus (secret) or incomprehensibilis (incomprehensible) to describe union with Christ." 27 Apparently, Calvin as a biblical theologian never feel ashamed to borrow the Pauline term, "a profound mystery"(Ephesians 5:32), to explain his understanding of our union with Christ. He is also comfortable to admit the limitations of human reason, because God is pleased to make use of our defects for our good. The purpose of this mystical union, for Calvin, "is to realize piety, worship, trust, reverence, love, gratitude and acknowledgment of God." 28 That also distinguishes Calvin from the Medieval mysticism, because he is more interested on "the effectual transformation of the believer through union with Christ" than discovering mysterious. ${ }^{29}$

\section{A Substantial Union}

While affirming the mystical nature of this union, Calvin, on the other hand, does speak of a substantial union. It means that the union is not merely a virtual communion with Christ's benefits, but it is so real and intimate that the believer can be said to be in union with the very substance of the resurrected and ascended humanity of Christ.

One can hardly miss Calvin's habitual use of the Latin word substantia (substance) when describing the intimate relation of the believer and Christ in their union. In his commentary on Ephesians 5:31, Calvin claims unequivocally that when we are united into the body of

\footnotetext{
26 Ibid.

27 Tamburello, Union with Christ, 89; The seven references to mystery may be found in Calvin, Institutes, II.12.7, III.11.5, IV.17.1, IV.17.9, IV.17.31, IV.17.33, IV.19.35.

28 Jeong Koo Jeon, "Unio cum Christo: The Work of the holy spirit in Calvin's Theology", PhD diss., Westminster Theological Seminary, 1998, 142.

29 Ibid., 140.
} 
Christ, "we share his substance" just as Eve shares the same substance with Adam. ${ }^{30}$ Calvin goes on saying:

All depends on this, that the wife was formed of the flesh and bones of her husband. Such is the union between us and Christ, who in some sort makes us partakers of his substance. We are bone of his bone, and flesh of his flesh, not because, like ourselves, he has a human nature, but because, by the power of his Spirit, he makes us part of his body, so that from him we derive our life. ${ }^{31}$

Here Calvin explicitly denies that this "sharing" or "partaking" of Christ's substance, merely mean Christ has a human nature like ours through his incarnation. For Calvin, we, in the mystical union, substantially become part of Christ's body by the power of His Spirit. In several other places, Calvin also declares that "we are incorporated with him (so to speak) into one life and substance",32 or we have "been made partakers of his substance, that we may also feel his power in partaking of all his benefits." 33 All of these demonstrates that Calvin's existential union with Christ is also a real and substantial union.

Is Calvin then advocating a sort of deification? After his lengthy study of Calvin's emphasis on the substantial union with Christ in Eucharist, William Evans helpfully points out that Calvin's concept of substantial union is not an unmediated communion with Christ's deity, but union with the incarnate humanity of Christ. ${ }^{34}$ In another word, believers do share with Christ's deity, or partake of the divine nature, but it is through our union with the humanity of Christ. It is "into his body Father has destined" us to be engrafted. ${ }^{35}$ Calvin also states it explicitly in his 1559 Institutes:

\footnotetext{
30 John Calvin, Commentary, Ephesians 5:32. Accessed December 6, 2016. http://www.ccel. org/ccel/calvin/calcom41.iv.vi.vi.html.

31 Ibid.

32 John Calvin, Commentary, 1 Cor 11:24. Accessed December 6, 2016. http://www.ccel.org /ccel/calvin/calcom39.xviii.iii.html.

33 Calvin, Institutes, IV.17.11.

34 William B. Evans, Imputation and Impartation: Union with Christ in American Reformed

Theology (Wipf \& Stock, 2009), 41.

35 Calvin, Institutes, III.24.5.
} 
I frankly confess that I reject their teaching of the mixture, or transfusion, of Christ's flesh with our soul. For it is enough for us that, from the substance of his flesh Christ breathes life into our souls-indeed, pours forth his very life into us-even though Christ's flesh itself does not enter into us. ${ }^{36}$

The humanity of Christ, "the substance of his flesh", is presented by Calvin as the channel through which Christ's very life is poured out into believers. Our substantial union with the very flesh and blood of Christ makes us partakers of that life. But how is this substantial union with "the very flesh and blood of Christ" accomplished, especially when "Christ's flesh itself does not enter into us"? Now we need to turn to the role of Holy Spirit, the bond of our mystical and substantial union with the humanity of Christ. We will see that Calvin's existential union with Christ is a spiritually-qualified substantial union (a real but non-local presence).

\section{A Spiritual Union}

As mentioned previously, the decreed objective union and election in Christ and the accomplished redemption in Christ must be actualized in the elects by Christ. Only when Christ "illumines us into faith by the power of his Spirit, at the same time so engrafts us into his body," says Calvin, "that we become partakers of every good." 37 That is the way, through the Spirit worked faith, Christ unites us with Himself and the way we receive all spiritual blessings.

Instead of over speculative on the metaphysical mystical union with the essence of Christ, Calvin emphasizes the mediator role of Holy Spirit, also Christ's Spirit, in our comprehension of the mystical union. It for example, is showed in his commentary on John 14:20,

We cannot, by indolent speculation, know what is the sacred and mystical union between us and him, and again, between him and the Father; but

36 Calvin, Institutes, IV.17.32.

Calvin, Institutes, III.2.35. 
that the only way of knowing it is, when he diffuses his life in us by the secret efficacy of the Spirit. ${ }^{38}$

Our oneness with the Son of God in the union is real and actual, but that is because of the power of the Spirit, not an unmediated convey of divine substance. ${ }^{39}$ Calvin also asserts that unless one is drawn by the Holy Spirit, he cannot be aroused to seek Christ, since Christ "unites himself to us by the Spirit alone." 40 Thus, it is "foolish and absurd to dream that we can receive Christ without the Spirit." 41

The principle work of the Holy Spirit is faith, which is the very instrument that engrafts us spiritually into the body of Christ. For this reason, Calvin also refers to faith as "the bond by which he (Christ) is united to us." 42 Sometimes faith is indeed mentioned as "the cause of our salvation," 43 but faith itself, for Calvin, does not have any intrinsic value or power. Faith only derives its value and power entirely from its object Jesus Christ. Accordingly, Calvin claims that faith cannot save us until "it engrafts us in the body of Christ," for "it does not reconcile us to God at all unless it joins us to Christ." 44 Therefore, it is the Spirit of Christ who implements the entire process of application of Christ's salvific work to us. To conclude, union with Christ in Calvin's theology is not physical union, but spiritual, yet, it is real and truly substantial union with the humanity of Christ.

\footnotetext{
38 John Calvin, Commentary, John 14:20. Accessed December 6, 2016. http://www.ccel.org/ ccel/calvin/calcom35.iv.iv.html.

39 John Calvin, Commentary, John 17:21. Accessed December 6, 2016. http://www.ccel.org/ $\mathrm{ccel} /$ calvin/calcom35.vii.v.html.

40 Calvin, Institutes, III.1.3.

41 John Calvin, Commentary, Ephesians 3:17. Accessed December 6, 2016. http://www.ccel. org/ccel/calvin/calcom41.iv.iv.iii.html.

42 John Calvin, Commentary, John 16:9. Accessed December 6, 2016. http://www.ccel.org/ ccel/calvin/calcom35.vi.ii.html.

43 John Calvin, Commentary, Luke 8:11. Accessed December 6, 2016. http://www.ccel.org/ ccel/calvin/calcom32.ii.xix.html.

44 Calvin, Institutes, III.2.30.
} 


\section{Participation in Christ in Barth}

Calvin adopts several different terms to explain the believer's "in Christ," which include "engrafting," "participatio Christi," "unio cum Christo," and so on. Nevertheless, Barth prefers the more dynamic term participatio Christi (participation in Christ) to describe the union between believers and Christ. According to Barth, "Calvin's doctrine of the participatio Christi has one weakness," which lacks the objective presupposition of participation in Christ. ${ }^{45}$ Consequently, Barth develops a twofold form of participatio Christi, which includes the objective de jure participation in Christ and the existential de facto aspect. ${ }^{46}$

\section{Objective Union-De Jure Participation}

In contrast to Calvin, Barth turns to emphasize the objective aspect of union with Christ, which is also a revolt of the prevalent subjectivism and mysticism in his age. As the Barth scholar Adam Neder observes, Barth's objective participatio Christi runs through his Church Dogmatics, but only reaches its fullest clarity in his doctrine of reconciliation, the fourth volume of Church Dogmatics. In the survey of the structure of his whole doctrine of reconciliation, Barth states:

We have to develop the whole doctrine of reconciliation in accordance with our Christology and the three basic christological aspects. We shall do so in three sections which correspond to the three aspects. The Christology is the key to the whole. From each of the three aspects suggested it will be our starting point and will necessarily control all the detailed developments. ${ }^{47}$

Apparently, Christology is the beginning and the center of Barth's doctrine of reconciliation.

\footnotetext{
45 Karl Barth, Church Dogmatics IV/2: The Doctrine of Reconciliation, $2^{\text {nd }}$ ed., ed. G. W. Bromiley and T. F. Torrance, trans. G. W. Bromiley (Edinburgh: T\&T Clark, 1958), 520. Each volume will be cited fully the first time, and thereafter simply with a $C D$ followed by a volume and part number.

46 See the discussion in Adam Neder, Participation in Christ: An Entry into Karl Barth's Church Dogmatics (Westminster John Knox Press, 2009), 18.

47 Barth, CD IV/1, 138.
} 


\section{De Jure Participation in Christ's Priestly Work in CD IV/1}

Barth, in CD 4.1, explores the humiliation of the very God even unto death on the cross, which brings the first Christological aspect of Barth's doctrine of reconciliation, justification. All man, according to Barth, have already participated in the humiliation of the very God on the Cross, and thus, been justified in Jesus Christ. What Christ achieves in his death at Golgotha, for Barth, is not only "a possibility," or "the setting up of a model and example," but the concrete actuality of "the death of all," which is realized "quite independently of their attitude or response to this event." 48

The crucifixion of Jesus Christ reveals the judgment of God, while His resurrection reveals the sentence of God, in which both the divine rejection of the elected man and the divine election of the rejected man take place. According to Barth, that also signifies "the fulfillment of our real rejection and also of our real election." ${ }^{49}$ Jesus's death is the death of all people of all time, which means all sinful man, "whether they hear and receive the news or whether they tried and still try to escape it," are died in Christ. ${ }^{50}$ It also means the extinguishing of the old man, the covenant-breaker. ${ }^{51}$ Therefore, Barth claims, "there is not one who is not adequately and perfectly and finally justified in Him."52 That is Barth's construal of the universal de jure justification of all humanity in Christ, which is one aspect of our de jure participation in Christ.

\section{De Jure Participation in Christ's Kingly Work in CD IV/2}

While man the covenant-breaker has ceased to be in the humiliation of Jesus Christ, it also comes the "creation of a new form of existence for man in which he can live as the loyal covenant-partner of God" in His

\footnotetext{
Barth, CD IV/1, 295, emphasis added.

Barth, CD IV/1, 516.

Barth, CD IV/1, 295.

Barth, CD IV/1, 93-94.

Barth, CD IV/1, 630.
} 
exaltation. ${ }^{53}$ In $C D$ IV/2, Barth talks about our sanctification under the second aspect of his Christology, Jesus Christ, the very man, the servant is exalted to be God, in which his objective participatio Christi appears again. "The God who in His humiliation justifies us is also the man who in His exaltation sanctifies us." ${ }^{54}$ In the divine act of atonement, Jesus Christ was not only, as God, humbled to take our place, but also, as man, was exalted on our behalf. Hence, justification and sanctification, for Barth, are only two aspects of one and the same action of Jesus Christ. Man's sanctification "is indissolubly bound up with his justification, i.e., in the fact that as He (Jesus Christ) turns to man in defiance of his sin, He also, in defiance of his sin, turns man to Himself." 55 They are the two aspects of single promise: justification means "I will be your God," and sanctification means "Ye shall be my people." 56 Thus, a new man is introduced by God "in the new form of existence of a faithful covenantpartner who is well-pleasing to Him and blessed by Him." ${ }^{57}$ This is the sanctification of man.

For Barth, the incarnation is the starting point of the exaltation of all humanity. In Jesus Christ, Barth says, "we have to do with the exaltation of the common essence to all men." 58 What the Christmas message tells us, then, is not only the divine humiliation, but also the union of God with our human existence, the exaltation of human essence, "which then took place uniquely in the existence of this man (Jesus Christ), prior to our attitude to it, before we are in any position to accept or reject it." 59 This Christmas message "speaks of what is objectively real for all men." 60 There is no one who is not elected in Him to the eternal grace of God, and therefore, there is no one "who does not participate in

\footnotetext{
Barth, CD IV/2, 514.

Barth, CD IV/2, 503.

Barth, CD IV/2, 499.

Barth, CD IV/2, 499.

Barth, CD IV/2, 499.

Barth, CD IV/2, 69

Barth, CD IV/2, 270.

60 Barth, CD IV/2, 270.
} 
Him in His turning to God...There is no one who is not raised and exalted with Him to true humanity". ${ }^{61}$ In spite of their sin, men, therefore, have received the freedom by participating in the Holy one and the sanctified one, the very man Jesus Christ. To conclude, "The sanctification of man, his conversion to God, is, like his justification, a transformation, a new determination, which has taken place de jure for the world and therefore for all men." 62

\section{De Jure Participation in Christ's Prophetic Work in CD $/ \mathrm{V} / 3$}

By participation in Christ's kingly and priestly works, man's authentic being, as well as the reconciliation of the whole world with God, has been achieved perfectly, with no need of supplement. What remains, however, is the revelation of this truth and its effectuation in the lives of God's people, which "occurs in and with reconciliation and is still the work of Jesus Christ, this time as prophet." 63 In the third Christological aspect, the God-Man, Barth turns to examine the prophetic work of Jesus Christ as the true witness of God in $C D$ IV/3, which brings the objective calling of man, the third aspect of the reconciliation of man in Jesus Christ.

Christ's priestly and kingly office, for Barth, should never be separated from His prophetic office. According to Barth, in this resurrection event, the particular existence of Jesus Christ "as an inclusive being and action enfolding the world " is manifested to all, which also attests Jesus Christ "as Word to all, as reconciliation revealed and not Hidden, as salvation manifest and not concealed", and more importantly, "as not merely the reality of the alternation accomplished in Him but also its eloquent truth." 64 And moreover, Jesus Christ, as the shining light of life, now continually "lives and proclaims Himself and

\footnotetext{
Barth, CD IV/2, 271.

2 Barth, $C D$ IV/2, 511.

63 G W. Bromiley, An Introduction to the Theology of Karl Barth (Edinburgh: T. \& T. Clark, 1979), 219.

64 Barth, CD IV/3, 283.
} 
the act of reconciliation accomplished in Him, the fulfillment of the covenant between God and man effected in Him". 65

As a result of that, the being of man acquires a new direction and destiny. According to Barth, "a new character and form" has been pronounced and imparted to man irrevocably in the resurrection of Jesus Christ, no matter "how man may twist and turn," which also means that all humanity has been addressed or called and altered in Jesus Christ, "even before he can hear and obey,"66 Apparently, what Barth has in mind here is the objective participation of all humanity in Christ's prophetic work, which is explicated further when he says:

Heaven and earth, angels and men and all creatures, are already in the resurrection of Jesus Christ set in the penetrating and transforming light of His person and work; they are already seized by that fire; they are already taught by Him, by the commencement of His prophetic work...It can only confess to all men and to the whole world that in its dimension as revelation, too, the work of Jesus Christ took place and takes place for them and to them. ${ }^{67}$

That is how Barth takes seriously of the resurrection event of Jesus Christ, though he denies its historicity. Thus, all humanity, by participation in Jesus Christ's true witness, has been called and has become the true witness of God's salvation, as "Jesus Christ did not only die for him. He also rose again and lives for him." 68

Now, it is sufficient to conclude that, for Barth, the whole humanity has already objectively participated in Jesus Christ's priestly, kingly and prophetic works, and thus, have been justified, sanctified and called irrevocably and once for all, no matter one recognize it or not. Thus, the difference between believers and unbelievers is not that believers are united with Christ and saved while unbelievers are not. On the contrary, both of them are bounded together by a solidarity in the

\footnotetext{
65 Barth, CD IV/3 491.

66 Barth, CD IV/3, 299.

67 Barth, CD IV/3, 304-305.

68 Barth, CD IV/3, 486.
} 
grace of participation in Christ. That is Barth's construe of participation in Christ de jure, which is to participate in the works and the life history of Jesus Christ actualistically.

\section{Existential Union-De Facto Participation}

Barth's de jure participation in Christ is so forceful that many scholars are troubling with the consequence of universalism and the elimination of human responsibility. While, Neder argues that "objective participation in Christ does not destroy or eclipse subjective human response," rather, it "establishes and guarantees genuine human subjectivity," which is Barth's de facto participation. ${ }^{69}$ Now, let us turn to examine the existential aspect of union with Christ in Barth's theology.

\section{The Context of Barth's Union with Christ}

The resurrection, for Barth, is just "the beginning, the primal and basic form" of Jesus Christ's prophetic being and work. ${ }^{70}$ Now, Jesus Christ is still "on the way" of His prophecy, moving and marching from the commencement of His revelation to its completion. ${ }^{71}$ Christ's resurrection is the beginning of the present era, and His goal will be the goal and end of world history. Thus, Jesus Christ, as the prophet, is Himself the meaning of history in this era between His resurrection and the end of world history. During this interval, Christ's parousia is in a second form, which Barth calls "the promise of the Spirit." But if Christ's resurrection was such a powerful event, why could we not see the irrevocable alternation of the world and man immediately? Why did not the entire world and all men also reach their goal of redemption at the same time as Jesus Christ? Is Jesus Christ unable to entirely defeat evil all at once?

\footnotetext{
69 Adam Neder, "'A Differentiated Fellowship of Action': Participation in Christ in Karl Barth's Church Dogmatics" (Ph.D., Princeton Theological Seminary, 2005), 116.

70 Barth, $C D$ IV/3, 328.

71 Barth, CD IV/3.1, 327.
} 
To answer that, we need to review the covenant context of Barth's participation in Christ. As mentioned previously, God in eternity once for all has determined Himself to be the Covenant-God of man, which also determines the true being of man as the covenant partner of God who can freely participate in the eternal glory of God. Namely, God's eternal covenant of grace includes within itself the goal of creating free human subjects who can actually be his partners, which, in Barth's words, "will be a being not only as object, but as an active subject in the fellowship of God with the created world and man... a being in man's own free responsibility with God for the cause of God." 72 That means Jesus Christ's objective work does not exclude, but must include within itself the subjective realization of this work as its goal. Namely, in line with Barth's actualistic spirit, the objective participation achieved by Christ is not a state but still an ongoing event or history, which includes the believer's subjective participation. The relationship of the two is that, the de facto subjective participation in Christ is the goal of de jure objective participation, while the de jure objective participation is the ground of the de facto subjective form. ${ }^{73}$ Thus, it makes sense that the living Christ, in His prophetic office and work, "cannot and will not remain alone," but "wills to be what $\mathrm{He}$ is and do what He does in company with others whom he calls," the Christians. ${ }^{74}$ In summary, for Barth, we are in the time of the interval simply because Christ wills us, God's covenant partner, to be on the way to the goal of consummation with Himself. ${ }^{75}$ Keith accurately summarizes that "this particular vision for the participation of human beings in the life of God within a single covenant history centered on Christ is the context from which Barth describes the believer's union with Christ." 76

\footnotetext{
72 Barth, CD IV/1, 113.

73 Neder, Participation in Christ, 18.

74 Barth, CD IV/3, 542.

75 Barth, CD IV/3.1, 333.

76 Keith L. Johnson, "Karl Barth's Reading of Pau1's Union with Christ" in 'In Christ' in Paul: Explorations in Paul's Theology of Union and Participation: Wissenschaftliche

Untersuchungen Zum Neuen Testament. 2. Reihe, ed. Michael J. Thate, Kevin J. Vanhoozer, and
} 
Hence, the fact of our election, justification, sanctification, and vocation actualized in Christ de jure, for Barth, does not result to our dissolution into Christ, but "our true and highest activation" to be free subject for covenant obedience. ${ }^{77}$ In His moving "from the one Easter Day to the day of all days, to the last day, to the day of His final and conclusive return," Jesus Christ is calling everyone to enter into union with Himself subjectively and to be the true covenant partner of God in obedience. ${ }^{78}$ Mankind, as reconciled creatures, are graciously given time and space and opportunity to exercise our freedom and realize our being, or sharing in the meaning of history, through participating in Christ's ongoing prophetic work, in other words, His victorious history, de facto. ${ }^{79}$ When an individual is addressed by Jesus Christ in the power of the Holy Spirit, and that person becomes a hearer of the Word, he is "illuminated, awakened and set in motion" to respond to the priestly, kingly and prophetic work of Jesus Christ. ${ }^{80}$ That actualization of the irrevocable reality of justification, sanctification and vocation in man's own history, for Barth, is the vocation of man to become a Christian, to participate in Christ de facto. Our study of Barth's de facto participation in Christ is found in this specific section§71.3 titled "The Goal of Vocation," in which Barth treats the theme of union with Christ as the goal of vocation. ${ }^{81}$

\section{The Character of Barth's Union with Christ}

According to Barth, although all humanity are elected in Jesus Christ "to their justification, their sanctification and also their vocation", 82 not all are called subjectively to be Christian and thus to be set in fellowship with Jesus Chris. ${ }^{83}$ Barth describes this special Christian existence em

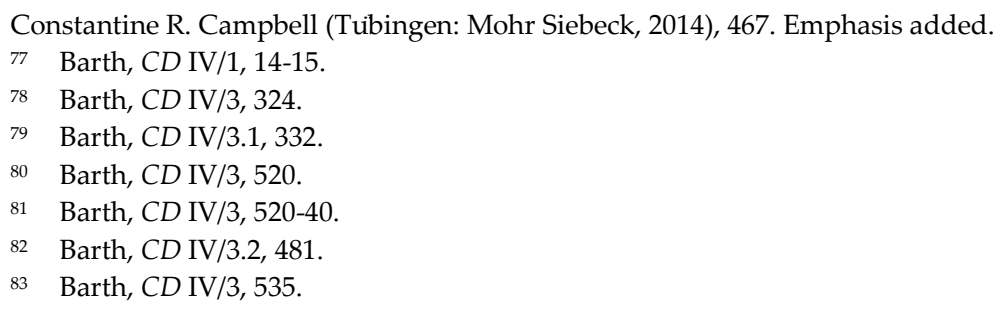


dash a perfect intimate fellowship with Christ, the believer's unio cum Christo, which is the ultimate goal of vocation. It is only by the gift and the power of the Holy Spirit that man's vocation becomes vocatio efficax. ${ }^{84}$ In this event of effective vocation, Barth says, man "freely delivers himself de facto to the One to whom He belongs de jure." 85

Barth rejects Calvin's term unio mystica in describing believers' existential union with Christ, but characterizes this union as a "true, total and indissoluble union: true and not ideal; total and not merely psychical and intellectual; indissoluble and not just transitory." 86 As a matter of fact, Barth develops an actualistic Chalcedonian pattern of union with Christ, in which "the indissoluble differentiation" and "the inseparable unity" relationship between Christ's two natures or essences are applied to describe believer's union with Christ. Barth explicitly states this way:

it belongs to the perfection of this fellowship, and must not be overlooked or denied, that in it Christ does not merge into the Christian nor the Christian into Christ. There is no disappearance or destruction of the one in favor of the other. ${ }^{87}$

Neither dissolution or disappearance of the one in the other, nor identification of the two, happens in our union with Christ. For Barth, this union as "a differentiated fellowship of action" takes place in a definite and irreversible order, in which "Christ is always superior and the Christian subordinate". ${ }^{88}$ As the primary Subject, Jesus Christ is always the one who calls, acts and rules as the Lord, while Christians always gratefully accepts His calling, acting and ruling as the obedient servant. Peter S. Oh also notices that this union, for Barth, is "never static or coercive but always fluid and reciprocal," in which Christ gives and Christian receives; Christ requests and Christian answers; Christ

\footnotetext{
84 Barth, $C D$ IV/3, 538.

Barth, CD IV/3, 536.

Barth, CD IV/3, 540.

Barth, CD IV/3.2, 539.

88 Barth, CD IV/3.2, 598.
} 
commands and Christian obeys. ${ }^{89}$ The order of this union, asymmetrically differentiated bipolar unity, is indestructible for Barth, no reversing and no confounding. Thus, both Jesus Christ's actions and free human actions occur as "a single totality, a fluid and differentiated but genuine and solid unity." 90 Or, put it another way, in Jesus Christ, God and humanity "live together (though not in identity) in the indestructible conjunction of the differentiated act in which both Creator and creature exist." 91 This is Barth's actualistic Chalcedonian pattern of union with Christ.

\section{The Content of Barth's Union with Christ}

Defining Christian as someone "called by God in Jesus Christ through the Holy Spirit," Barth further explains that Christians are not called for their own salvation and benefits only, neither are they merely called to live a moral life nor to persuade others to receive salvation; rather, "to be called means being given a task." ${ }^{92}$ So Christians are called to be a responsible witness of Jesus Christ:

Whether strong or weak, willing or unwilling, successful or unsuccessful, the Christian is a witness, irrespective of whether the miracle occurs, or whether it occurs visibly or invisibly. In all circumstances and with his whole existence he is a responsible witness of the Word of God. He is called to be this. ${ }^{93}$

This vocation to be a witness, for Barth, defines the whole existence of Christian. "The vocation to be a Christian is essentially and decisively the vocation to be a witness." 94 Therefore, to be in union with Christ, for Barth, first and foremost means to be in union with Christ in His

\footnotetext{
89 Peter S. Oh, Karl Barth's Trinitarian Theology: A Study in Karl Barth's Analogical Use of the Trinitarian Relation (London: T \& T Clark, 2006), 155.

90 Barth, $C D$ IV $/ 3,540$.

91 Barth, $C D$ IV $/ 3.1,40$.

92 Barth, $C D$ IV $/ 3,573$.

93 Barth, $C D$ IV $/ 3,609$.

94 Barth, $C D$ IV/3, 618.
} 
prophetic work, which means to be a witness of Jesus Christ's priestly and Kingly works.

Just as Jesus Christ works "by the free choice and decision of His free love for the world," Christians, in whom Christ lives and who live in Christ, also work analogously, and "does so in perfect fellowship with the working of Christ." 95 Sent and commissioned by Jesus Christ, believers "become with Him proclaimers of the reconciliation of the world accomplished in Him, heralds of His person and work." 96 In this co-operation, "the action, work or activity of Christ unconditionally precedes that of the man called by Him, the Christian, and that of the latter must follow." 97 Following Christ's self-witness, and thus, participation in the history of salvation, Christians manifest, indicate and attest with their whole existence to other man "what is said to him and received by him as a Word of reconciliation directed not to him alone but to the whole world and all men." 98 That is Christian's "witness in analogy" to the true witness of Jesus Christ, which is not out of any need or necessity, but only becomes possible and effective by the free divine grace and in the power of the Holy Spirit. ${ }^{99}$ Another distinctive mark of Christian life in union with Christ, for Barth, is affliction, which arises out of Christian witness unavoidably. Although Christian witness "is the primary determination of Christian existence," Barth claims, "none can be a Christian without falling into affliction." 100 If a Christian does not feel oppressed by his environment and experience no affliction, then, one should reason carefully and ask himself/herself whether he/she is genuinely a Christian or not. ${ }^{101}$ To conclude, it is through the self-witness of Jesus Christ that the Christian is called to be the witness, and it is by

\footnotetext{
95 Barth, CD IV/3, 597-598.

96 Barth, CD IV/3, 606.

Barth, CD IV/3, 598.

98 Barth, CD IV/3, 609.

99 Barth, CD IV/3, 609.

100 Barth, CD IV/3, 618.

101 Barth, CD IV/3, 619.
} 
the grace and power of Christ's Spirit that the Christian's witness becomes truly meaningful and valuable in the sight of God.

This individual witness or union with Christ, according to Barth, is enacted through the awakening power of the Spirit in our active obedience of faith, love and hope, which correspond to our objective justification, sanctification and vocation in Jesus Christ. Just as Jesus Christ, the "God with us" man, fulfills the divine-human union in His fully obedient life history, Christian's witness or subjective participation in Christ occurs in active obedience to God's commandment analogously. For Barth, Christians, sharing in Jesus Christ's divine-human obedience in the union, becomes "an active co-subject and cooperator" of the divine work in Jesus Christ. ${ }^{102}$

As the authentic response to God's faithfulness, faith, Barth writes, is wholly and utterly the humility of obedience. ${ }^{103}$ In faith, humans, on one hand, affirm their pride and see the corruption of their proud action, while on the other hand, he/she apprehends and accepts "the crucified and risen Jesus Christ who lives as the author and recipient and reveler of the justification of all man." 104 As one aspect of believer's subjective union with Christ, this personal faith "constitutes the Christian," Barth writes, because "in believing, the Christian owes everything to the object of his faith (Jesus Christ), the incomprehensible fact that he may not only be in relation to this object, but may be active in this being." 105 Following from Jesus Christ's kingly work, the obedience of love in practice is the "second form of the particular being of the Christian in Jesus Christ." 106 Barth explicitly writes, "that one can love is (due to) the work of the Holy Spirit which makes he/she a Christian." 107 The close relation between justification and sanctification for Barth decides that love cannot be

\footnotetext{
102 Peter S. Oh, Karl Barth's Trinitarian Theology, 152-153.

103 Ibid., 618-620.

104 Barth, CD IV/1, 629.

105 Barth, CD IV/1, 742. Emphasis added.

106 Barth, CD IV/1, 102.

107 Barth, CD IV/1, 13.
} 
separated from faith, but they must be distinguished as two moments of one divine act. Love as self-giving, Barth says, "stands contrasted with faith as reception." 108 In this sense, love is the authentic act of witness.

Hope is understood by Barth "as the third form of the work of Holy Spirit that makes man a Christian". ${ }^{109}$ The reason that hope is an essential aspect of Christian's union with Christ in obedience, for Barth, is that Jesus Christ in His prophetic work is still on the way to the consummation. Thus, genuine Christian hope, holding to the confession "Jesus is Victor!" is a witness and service in action aiming at the ultimate consummation, rather than merely static expectation. ${ }^{110}$ In the obedient act of hope, man lives to the service and witness of the Word of God with all his thoughts and words and works. At the end, Barth summarizes Christian life, in response to the three forms of Christ's parousia, as that He "believes (a parte potiori) in the One who came then, that he loves (a parte potiori) Him as the One who is present now and that he hopes (a parte potiori) for His new coming one day."111

\section{Comparison and Evaluation}

Now I will bring together the work of the previous study through a comparison. It is my argument that Calvin and Barth's contrasting ontological presuppositions inevitably results to Calvin and Barth's distinct characterizing of union with Christ.

\section{Similarities}

The divergence of Calvin and Barth becomes greater when it comes to the doctrine of union with Christ itself. On the whole, both Calvin and Barth, to a certain degree, have a twofold union in mind, objective de jure union and subjective de facto union. Although it is only suggested implicitly, an

\footnotetext{
108 Barth, $C D$ IV/2, 730.

109 Barth, CD IV/1, 108.

110 Barth, CD IV/3.2, 938-939.

111 Barth, CD IV/3, 911. Emphasis added.
} 
objective eternal union of the elects with Christ does appear in Calvin's mind. The engrafting of the believer into the body of Christ, according to Calvin, has been predestined by God the Father in His willing of election in eternity, from where the believer's assurance of salvation derives, and thus, their perseverance. Accusing Calvin's lacking of the objective presupposition of participation in Christ, Barth put much more emphasis on the objective aspect of our union with Christ. Our eternal election "in Christ", for Barth, means our objective participation in Christ from all eternity, in His grace, in His covenant, in His history, in His faithfulness. ${ }^{112}$ Thus, "no man is rejected, but all are elected in Him to their justification, their sanctification and also their vocation." 113 Apparently, Barth does not only explicitly proposed an objective eternal participation of the elects in Jesus Christ, but also an objective incarnational union of all humanity with Jesus Christ in His life history of incarnation.

While maintaining the objective aspect of our union with Christ, both of the two theologians also highly value the subjective existential aspect of union, which, for them, is the starting point of what makes Christian a Christian. ${ }^{114}$ Referring to Calvin's 1559 Institutes, Barth accurately notices that the existential aspect of union with Christ functions as the common denominator under which Calvin ranges his whole doctrine of salvation. Thus, this notion, according to Barth, is Calvin's conception of "the essence of Christianity." 115 In the mind of Barth himself, union with Christ is even considered as what makes man a man, which means it is the only way to realize of our true being as the covenant-partner of God. While explicating the nature of this existential union, the two theologians similarly reject the notion of deification, but insist a real and intimate union without dissolution or confusion. For Barth, the reason that God becomes man is not for man to become God,

\footnotetext{
112 Barth, $C D \mathrm{II} / 2,121$.

113 Barth, $C D$ IV $/ 3,482$.

114 Barth, CD IV/3, 548; Calvin, Institutes, III.1.1.

115 Barth, CD IV/3.2, 551-552.
} 
but to make man the obedient covenant partner of God, which is the original purpose of God's creation.

The role of Holy Spirit in the existential union is also acknowledged by both Calvin and Barth. As the theologian of Holy Spirit, Calvin considers the Holy Spirit "as the bond by which Christ effectually unites us with Himself", and the one who communicates all the benefits of Christ to us. ${ }^{116}$ There are many criticism on Barth for his weak pneumatology. In line with his Christ-centered focus, Barth frequently refers to the Holy Spirit as Christ's Spirit. "Thus, the only content of the Holy Spirit is Jesus; his only work is his provisional revelation; his only effect the human knowledge which has [Jesus] as its object." 117 However, that does not mean the crucial role of the Holy Spirit is ignored, especially concerning His doctrine of existential union with Christ. For Barth, "the work of the Holy Spirit is to bring and to hold together that which is different." 118 Just as the Holy Spirit effects the union of Jesus Christ's divine and human nature in the incarnation, it is also "in the divine power of His Spirit He (Jesus Christ) unites Himself with them." 119

\section{Differences}

The apparent difference between Calvin and Barth should be their contrast emphasis on the objective and subjective union. Obviously, Barth's focus is always on the primacy of the objective reality, while, Calvin is on the existential subjective side. In the following, I will adopt Hunsinger's terminology of soteriological objectivism and soteriological existentialism to categorize Barth and Calvin's differences on the teaching of union with Christ.

Soteriological objectivism is the fruit of Barth's construction of participation in Christ. For Barth, all humanity is eternally enclosed objectively in Jesus Christ, the only elect of God, by way of anticipation.

\footnotetext{
116 Calvin, Institutes, III.1.1-3.

117 Barth, CD IV/2, 654.

118 Barth, $C D$ IV/3, 761.

119 Barth, CD IV/3.2, 542.
} 
All God's ways and works begin with this free grace of election, the whole of the Gospel, Jesus Christ. Thus, there is an eternal objective union between all humanity and Christ, which transcends humanity's personal existence. Besides this predetermined universal eternal union, Barth also endeavors to explicate the historical objective union between all humanity and Jesus Christ in the event of His incarnation. The history of Christ's incarnation, for Barth, is also the historical fulfilling of the eternal covenant between God and man on both sides perfectly. ${ }^{120}$ Restoring the covenant fellowship with God, Jesus Christ also creates the true human nature in His obedient action as covenant partner of God. Thus, an "ontological connection" is established "between the man Jesus on the one side and all other men on the other", and all humanity "can be claimed as His de iure." 121 Based on that, Barth claims "What has happened in Him (Jesus Christ) as the one true man is the conversion of all of us to God, the realisation of true humanity." 122 The history of Jesus Christ's incarnation itself, therefore, is our reconciliation with God. ${ }^{123}$ To conclude, this Christmas message "speaks of what is objectively real for all men, and therefore for each of us, in this One." 124 This is Barth objective incarnational union between all humanity and Christ, which is the space-time continuum of the pre-temporal eternal union.

Barth's objective emphasis of the "predestination" and "redemptive-historical" in Christ basically leaves no room for believer's existential subjective union with Christ. As he writes, "when the Holy Spirit draws and takes us right into the reality of revelation by doing what we cannot do, by opening our eyes and ears and hearts, he does not tell us anything except that we are in Christ by Christ." 125 Namely, for Barth, this existential subjective union with Christ has nothing to do with

\footnotetext{
120 Barth, CD IV/1, 54.

121 Barth, $C D$ IV/2, 275.

122 Barth, $C D$ IV/1, 131.

123 Barth, $C D$ I/2, 173.

124 Barth, $C D$ IV/2, 270.

125 Barth, CD I/2, 240.
} 
one's personal salvation, which has already been enclosed in the history of Jesus Christ and nothing can be added to that. Nevertheless, the existential union with Christ, for Barth, functions crucially as the only way to live out one's true status and realize his or her authentic being as the covenant-partner of God. Moreover, we should also remember that Barth's conception of Christian's existential union with Christ is actualistic in nature. Adopting the "doing" word participation, rather than the "being" word union, Barth advocates a dynamic union with Christ's work, specifically with Christ's ongoing prophetic work of witness. In fact, Barth, unsatisfied with Calvin's duplex gratia of justification and sanctification, develops a threefold grace of Christ, justification, sanctification and witness. For Barth, only witness is closely related to Christian's existential union with Christ, and thus, functions as the goal of all humanity's objective justification and sanctification. "The Christian is thus liberated but also summoned to manifest, indicate and attest what is said to him and received by him as a Word of reconciliation directed not to him alone but to the whole world and all men", which, Barth claims, is "the meaning of the life of Christ in him and his life in Christ, the ratio of his Christian existence." 126 That is how Barth defines Christian's existential dynamic union with Christ.

Contrast to Barth, Calvin arrives at very different understanding of the function and nature of union with Christ, which should be classified as soteriological existentialism. For Calvin, our union with Christ also extends from eternity to eternity, but that only works for the particular chosen elects, rather than all humanity. Moreover, Calvin's chief interest, in line with the biblical emphasis, is believers' existential union with Christ. The elects' predestination "in Christ" and redemptive-historical "in Christ" through Christ's incarnation, for Calvin, should not in any way undermine the critical moment of believers' subjective union with Christ by the Spirited worked individual faith in real time. As long as this existential union with Christ is not effected, Calvin insists, "all that he

126 Barth, CD IV/3.2, 609. 
(Christ) has suffered and done for the salvation of the human race remains useless and of no value for us". ${ }^{127}$ Thus, Calvin's existential union with Christ is saving in nature, hence, is decisive in each individual's salvation. By affirming this point, Calvin also safeguards the indispensable role of Holy Spirit in our salvation. With Holy Spirit as the bond, believers' existential union with Christ, in Calvin's mind, is a substantial union in nature. Unlike Barth's emphasis of "union of doing", Calvin, holding the classical metaphysics and essentialist ontology, stresses the aspect of "union of being". In their union with Christ by the Holy Spirit, what believers receive are not merely the benefits of Christ's work, but more importantly, the very flesh and blood, the substance, the very being, of the incarnate Christ. But that does not mean our existential union with Christ is merely a state. Calvin also understands it as a dynamic process, in which Christ "grows more and more into one body with us", until Christ "becomes completely one with us". ${ }^{128}$

In summary, Calvin and Barth both have the concept of objective and subjective union with Christ in mind. But as the philosophical and epistemological context shifted, Karl Barth, the $20^{\text {th }}$ century theologian, replaces Calvin's classical essentialist ontology with the actualistic ontology to answer the challenges after Kant, which, therefore, results to his departure from Calvin on the doctrine of union with Christ. To counter the prevalent subjectivism in liberal theology and dead orthodox in his age, Barth, in contrast to Calvin, develops a forceful objective participatio Christi, and put more emphasis on the aspect of "union with doing". While, Calvin's focus is on our subjective existential union with Christ, which he explicates from the perspective of "union of being". Now, it is the time to give an evaluation of the two great theologians' doctrine of union with Christ.

127 Calvin, Institutes, III.1.1.

128 Calvin, Institutes, III.2.24. 


\section{Evaluation}

It is the general consensus among Barth interpreters that Barth's doctrine of election necessarily and logically implies universalism, though Barth himself explicitly denies that. ${ }^{129}$ In light of Barth's doctrine of participatio Christi, Barth's universalism tendency only becomes more explicit. For Barth, all humanity elected in the God-man Jesus Christ in eternity have participated in Christ de jure. Thus, ontologically speaking, there is no one "who does not participate in Him in His turning to God" to enjoy the fellowship with God. ${ }^{130}$ This ontological universal de jure participatio Christi as the driving force calls for everyone to epistemologically recognize their true status already achieved in Christ and existentially live out their authentic being as God's covenant partner, which is the believer's union with Christ de facto. As it shows, Barth's teaching of subjective union with Christ is relatively weak, in the sense that it has nothing to do with one's ontological salvation. The death of Christ is not only sufficient and efficient for all humanity, but indeed atones for the sins of all men, which does not merely create a possibility but a reality of salvation. The nonbelievers may reject their election and refuse to participate in Christ de facto, which, for Barth, is the incomprehensible fact of the impossible possibility of sin, but that rejection does not and cannot change their redeemed true status in Christ. ${ }^{31}$ Thus, the only difference between Christians, who are in union with Christ de facto, and other non-Christians, according to Barth, is "experience and knowledge."132

\footnotetext{
129 See Bloesch, Balthasar, Berkouwer and Brunner's interpretations. Donald G. Bloesch, Jesus Is Victor!: Karl Barth's Doctrine of Salvation (Nashville: Abingdon, 1976), 70. Hans Urs von Balthasar, The Theology of Karl Barth, trans. John Drury (New York, Chicago, San Francisco: Holt, Rinehart and Winston, 1971), 163. G. C. Berkouwer, The Triumph of Grace in the Theology of Karl Barth (Grand Rapids: Eerdmans, 1956), 121. Emil Brunner, Dogmatics I: The Doctrine of God, trans. Olive Wyon (London: Lutterworth Press, 1949), 349.

130 Barth, CD IV/2, 271.

131 Barth, CD II/1, 505.

132 Barth, CD IV/1, 92.
} 
However, Barth's Christocentric actualistic construal of union with Christ makes his universalism tendency bear some unique features. Obviously, Barth, if being coherent, should claim himself to be a universalist, yet he denies it and suggests that we should be open for the final eschatological consequence, because we cannot limit the God who loves in freedom. ${ }^{133}$ Michael Horton rightly notes that Barth's tendencies towards universalism are not motivated by the superficial liberal optimism, but by a "hyper-Calvinistic" doctrine of grace, which emphasizes God's absolute sovereignty. ${ }^{134}$ Therefore, while criticizing Barth's universalism tendency, we should also appreciate his concern of securing God's sovereign freedom and defensing the Reformed tradition of monergism in his age.

Moreover, Barth, unlike the hyper-Calvinism and classical universalism, highly values evangelism, or witness in Barth's own word. The ministry of witness, for Barth, "is the primary determination of Christian existence", 135 or "the essence" of our vocation as Christian. ${ }^{136}$ Namely, to be a Christian means to act the Christ living, which is to unite with the prophetic work of Christ in witnessing. Therefore, what Barth tries to do with his dialectic expression of universalism is actually to maintain the biblical tension between the universalism of divine intent and the eschatological particular redemption. ${ }^{137}$ We should note that Barth never denies reprobation and eternal punishment as the classical universalism. Instead, he has a vivid description of God's punishment on the reprobate one-Jesus Christ. While on the other side, both the classical universalism and hyper-Calvinism fail to maintain that tension in their own way, and thus, end up with diminishing the importance of evangelism, which is totally unacceptable for Barth. So, it seems that

\footnotetext{
133 Barth, CD II/2, 417-18.

134 See Michael S. Horton, "A Stony Jar: The Legacy of Karl Barth for Evangelical Theology" in Engaging with Barth, 364-65.

135 Barth, $C D$ IV/3, 618.

136 Barth, $C D$ IV/3, 575.

137 Bruce L. McCormack and Clifford B. Anderson, eds., Karl Barth and American Evangelicalism (Grand Rapids: Eerdmans, 2011), 229-30.
} 
Barth is more concerned with the free offering of the gospel to each individual than giving arbitrary eschatological conclusions by limiting the freedom and grace of God. To conclude, it is out of question that Barth has a strong desire and great hope for universal salvation, but he does not just stop there and speculate the ultimate eschatological destiny of each individual. Rather, he emphasizes forcefully that each Christian should, by union with Christ de facto, participate in the victorious Christ's prophetic work and mission to actualize that universal salvation.

Compared with Barth, Calvin has a relatively weak objective union with Christ in mind, which is more like an appendix to his soteriology. Only when the elects are in union with Christ existentially by the Spirit worked saving faith, can they look into the mirror of election, Christ, to realize their objective in Christ since eternity. Probably we can even say that, for Calvin, the believer's saving faith does not only effect his subjective union with Christ, but also, in one sense, his objective union with Christ. In this way, Calvin's teaching of the eternal objective in Christ functions as the assurance of our salvation after we become Christians and are saved existentially. But from another perspective, Calvin successfully holds together the objective and subjective poles of salvation, and thus the harmony of the Trinitarian work. The elects' eternal objective "in Christ" by God the Father is executed in time by the incarnational life of God the Son, which effects an objective incarnational union between Christ and the people represented by Him. Succeeding the work of God the Father and God the Son, God the Holy Spirit continues to apply the accomplished objective salvation to the elects subjectively by engrafting them existentially to the body of Christ through faith, which is the believers' existential saving union with Christ. For Calvin, the objective aspect of union with Christ is just as vital as the subjective aspect, so does the work of God the Father, God the Son and God the Holy Spirit.

Barth, however, fails to maintain that balance. His objective de jure participation in Christ apparently is in a dominating position, which 
includes the de facto aspect. As a matter of fact, both the objective aspect work of God the Father and the existential aspect work of the Holy Spirit are merged into Barth's Christology, the objective incarnational life of Jesus Christ. For Barth, it is the God-man Jesus Christ, rather than the unknown God the Father, who is the Elector. The transfer of sinners from the state of wrath to the state of grace is also not achieved by the Holy Spirit, but by the incarnational representative life of Jesus Christ. And now, it is also Jesus Christ in His final parousia who is calling each individual to participate in His history and His prophetic ministry of witnessing, rather than the Holy Spirit. Therefore, it is not without reason that Barth's Christocentrism has often been accused of "Christomonism". While, Calvin presents his Christocentrism in a very delicate way, which reflects his emphasis on the existential soteriology. Barth is wrong to accuse Calvin of neglecting Christ's electing role. Nevertheless, Calvin refers to Christ as the author of election together with God the Father, and it is out of his soteriological concern to demonstrate that our election and assurance of salvation is in Christ, by Christ, and known through Christ as well. Similarly, when speaking of the vital role of Holy Spirit in our existential salvation, Calvin also emphasizes it is the body of Christ that the Spirit binds us to. To conclude, it seems that Calvin's understanding of our objective and subjective union with Christ, in a better way than Barth's, presents the perfect harmony of the Trinitarian work in our salvation, while highlighting the centric role of Jesus Christ.

To summarize, indeed there are some similarities and continuities between Calvin and Barth's understanding of union with Christ, but those are only on the superficial level of terminology. The differences and divergences between the two theologians are even more, which, more importantly, are rooted in their fundamental presuppositions. Thus, this thesis argues that Barth does not only depart from Calvin in his doctrine of predestination and election as he claims, but also in his whole doctrine of participation in Christ or union with Christ, though he continues to use the terms from Calvinist tradition. It does not necessarily mean, 
however, that Barth's doctrine of participation in Christ is totally wrong and should be deserted totally. By placing Barth back into his historical context, we are able to appreciate more of his efforts to answer the various epistemological and metaphysical challenges of his age. Although Barth's "overcome Kant by means of Kant" seems not so promising, it is undeniable that he reintroduces the classical and Reformed tradition to the modern theological world, and kindle the interests in the doctrines of Trinity, Bibliology, Christology, and so on. In that sense, he is unquestionably the greatest Reformer of Christianity in $20^{\text {th }}$ century. However, the right way to going forward sometimes is by going back first, holding onto the traditional biblical presupposition, and recovering the best of the Reformed tradition such as Calvin's! 